\title{
Chemical composition, antibacterial and antioxidant activities of essential oils extracted from dry and fresh Brocchia cinerea
}

\author{
NISRINE CHLIF ${ }^{1, \bullet}$, ABDELAZIZ ED-DRA ${ }^{2}$, MOHAMMED DIOURI ${ }^{3}$, NOUREDDINE EL MESSAOUDI ${ }^{4}$, \\ BADR ZEKKORI ${ }^{1}$, FOUZIA RHAZI FILALI ${ }^{2}$, AMAR BENTAYEB ${ }^{1}$ \\ ${ }^{1}$ Research Group of Physical-Chemistry of Condensed Matter, Department of Chemistry, Faculty of Sciences, Moulay Ismail University. Zitoune Meknes \\ 11201, Morocco. Tel.: +212-636250593, ^email: nisrin.chliff@ gmail.com \\ ${ }^{2}$ Research Group of Microbiology and Health, Laboratory of Chemistry-Biology Applied to the Environment, Department of Biology, Faculty of \\ Sciences, Moulay Ismail University. Zitoune Meknes 11201, Morocco \\ ${ }^{3}$ Laboratory of Plant Biotechnology and Molecular Biology, Department of Biology, Faculty of Sciences, Moulay Ismail University. Zitoune Meknes \\ 11201, Morocco \\ ${ }^{4}$ Laboratory of Applied Chemistry and Environment, Ibn Zohr University. Agadir 80000, Morocco
}

Manuscript received: 24 January 2021. Revision accepted: 10 March 2021.

\begin{abstract}
Chlif N, Ed-Dra A, Diouri M, Messaoudi NE, Zekkori B, Filali FR, Bentayeb A. 2021. Chemical composition, antibacterial and antioxidant activities of essential oils extracted from dry and fresh Brocchia cinerea. Biodiversitas 22: 1741-1749. Brocchia cinerea Vis. is a medicinal plant belonging to the Asteraceae family, widely used in traditional medicine and as a food condiment by southeast Moroccan populations. This study aimed to determine the chemical composition of essential oils (EOs) of fresh and dry aerial parts of $B$. cinerea and to evaluate their antibacterial and antioxidant activities. Chemical composition was determined by GC-MS and antibacterial activity was performed against six pathogenic bacteria. Moreover, the antioxidant activity was evaluated by ferric reduction antioxidant power and DPPH scavenging assay. The main components of fresh plants were thujone (26.05\%), cis-chrysanthenyl formate (15.64\%), 2-champhanone (15.40\%), and santolina-triene (10.68\%). Whereas, the major components of the dry plant were thujone $(22.37 \%)$, santolina-triene (16.45\%), 1,8-cineol (12.19\%), and chrysanthenyl formate (12.03\%). The EOs exert a bactericidal effect against both Gram-positive and Gram-negative bacteria. However, the antioxidant assays showed that EOs of fresh and dry aerial parts of $B$. cinerea could reduce iron and trap DPPH radical. In a nutshell, this study showed that the EOs of fresh and dry aerial parts of $B$. cinerea are rich in natural substances that had interesting biological activities and can be used in the medical, pharmaceutical, and agri-food sectors.
\end{abstract}

Keywords: Antibacterial activity, antioxidant activity, Brocchia cinerea, Cotula cinerea, essential oil

\section{INTRODUCTION}

Arid regions are rough and constraining environments for the survival of living beings. Because these regions are characterized by a weak and irregular pluviometry accentuated by too high or very low temperatures, depending on the seasons, in addition to the constants winds. However, some areas offer favorable conditions for the growth of spontaneous and diversified flora (Barkaoui et al. 2017; Ben Haj Yahia et al. 2019; El-Hilaly et al. 2003; Jamila and Mostafa 2014; Silalahi et al. 2018; Mrabti et al. 2019).

The richness and diversity of plant flora in the arid regions can present an important source for scientific researches in different fields, including medicine, pharmacology, food, etc. These researches could participate in the development of the economic situation of the local population. The Southeast region of Morocco is rich in medicinal plants and characterized by the growth of a spontaneous plant called Brocchia cinerea (El Guertoufa in the local population) which belong to Asteraceae family (Jamila and Mostafa 2014).

Brocchia cinerea Del., syn. Cotula cinerea L., is a xerophytic plant widely distributed in sandy and desert grounds (Markouk et al. 1999; Djellouli et al. 2015). It is a small and annual plant, which appears as soon as the rains are over. It has a woolly aspect of 5 to $15 \mathrm{~cm}$ and entirely tomentose. Their stems are upright or diffused and the leaves are woolly whitish, thick, divided in their upper parts into three to five obtuse teeth. However, the flowers are small yellow gold halves of pompoms at the end of a short stem (Lakhdar 2018). The attachment of this plant to the Asteraceae family and particularly to anthemideae tribe gives it a precious chemical composition, in which flavonoids, sesquiterpenes lactones, and the polyacetylenes were the most characteristics compounds (Adekenov 1995; Ghouti et al. 2018a; Larbi et al. 2018; Guaouguaou et al. 2019).

Brocchia cinerea Vis. is rich in secondary metabolites and it is widely used in traditional medicine, suggesting interesting biological activities, especially antiinflammatory, analgesic, disinfectant, antibacterial, antipyretic (Ghouti et al. 2018b; Lakhdar 2018), and can be used against larvae of Anopheles labranchiae (Markouk et al. 2000). Therefore, it is used in traditional medicine for the treatment of various diseases, including digestive problems, rheumatism, urinary and pulmonary infections (Jamila and Mostafa 2014; Atef et al. 2015; Djellouli et al. 2015). Moreover, it is used to flavor traditional tea and preserve goat butter (Djellouli et al. 2015). Unfortunately, 
limited works were studied the biological activity of essential oils (EOs) of B. cinerea and none has compared the properties of EOs extracted from the dry and fresh plant. In this context, we aim to characterize the chemical composition of EOs extracted from dry and fresh aerial parts of $B$. cinerea and to evaluate their antioxidant capacity as well as their antibacterial activity against pathogenic bacteria.

\section{MATERIALS AND METHODS}

\section{Collection of plant material}

The plant material consisting of the aerial part of $B$. cinerea (Figure 1) was harvested in the flowering period during April 2017, in the region of Alnif city (Southeast of Morocco), especially in the town H'ssia (Figure 2). The site of the harvest of $B$. cinerea plant falls within the semi-arid

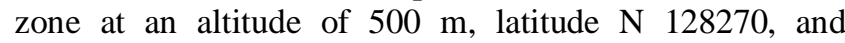
longitude E 078240. The plant was identified by Professors Mohamed Ibn Tattou and Hamid Khmmar, Scientific Institute of Rabat (Morocco). A voucher specimen was deposited in the National Herbarium of the Department of Botany in the Scientific Institute of Rabat under the number code "RAB 110972". Afterward, the harvested $B$. cinerea was divided into two equal parts; the first part was dried under room temperature for 15 days in the absence of light with normal humidity. However, the second part was used immediately for the extraction of EOs.

\section{Essential oils extraction}

The extraction of EOs was performed by hydrodistillation. In a round glass flask of 2 L, 200 grams of fresh and dry aerial parts were immersed separately in $1 \mathrm{~L}$ of distilled water and boiled for $3 \mathrm{~h}$ using Clevenger-type apparatus. The obtained EOs were dried by adding anhydrous sodium sulfate and stored at $4{ }^{\circ} \mathrm{C}$ until use. The EOs yield (\%) was calculated using the following formula (Ed-Dra et al. 2020):

$$
\text { Yield of EO }(\%)=\frac{\text { mass of EO obtained }(\mathrm{g})}{\text { mass of dry matter }(\mathrm{g})} \times 100
$$

\section{Gas Chromatography-Mass Spectrometry (GC-MS) Analysis}

The Gas Chromatography/Mass Spectrometry (GC-MS) analysis was performed by a TRIPLUS RSH gas chromatographer coupled with a mass spectrometer ISG The fragmentation was performed by electron impact at 70 $\mathrm{eV}$. The column used was a capillary column (100\% phenyl methyl siloxane: $30 \mathrm{~m}$ x $0.32 \mathrm{~mm}$ id, film thickness: 0.25 $\mu \mathrm{m})$. Both injector and detector temperatures were $250{ }^{\circ} \mathrm{C}$. The carrier gas is helium whose flow is fixed at 1.5 $\mathrm{mL} / \mathrm{min}$ and the split ratio was $1 / 10$. For the chromatographic analysis, EOs were diluted in cyclohexane $(1 / 20 \mathrm{v} / \mathrm{v})$. The column temperature was programmed from 50 to $200{ }^{\circ} \mathrm{C}$ at a heating rate of 4 ${ }^{\circ} \mathrm{C} / \mathrm{min}$, during $5 \mathrm{~min}$. The EOs components were identified by comparing the retention indices of authentic materials with those of substances present in the mixture and by further confirming their identities MS (library of NIST 98 spectra).

\section{Antibacterial activity}

The antibacterial activity of EOs was performed using the disc diffusion method to determine the area of the inhibitory diameter, and broth dilution on microplates to determine the Minimal Inhibitory Concentration (MIC) and Minimal Bactericidal Concentration (MBC). This activity was performed against six pathogenic bacteria belonging to Gram-negative and Gram-positive bacteria: Escherichia coli ATCC 25922 (EC) as a reference strain, Staphylococcus aureus (SA), and Salmonella Kentucky (SK) were isolated from meat products at the laboratory of Microbiology (Faculty of Sciences, University Moulay Ismail, Morocco). However, Klebsiella pneumonia (KP), Pseudomonas aeruginosa (PA), and Streptococcus faecalis (SF) were collected from the regional hospital of Meknes (Mohamed V Hospital), Morocco.

\section{Disc diffusion method}

The determination of inhibitory diameters area was performed according to the protocol described by Ed-Dra and his group (Ed-Dra et al. 2020). Briefly, bacterial suspensions equivalent to 0.5 MacFarland were prepared and inoculated on Mueller Hinton agar (Biokar, Beauvais, France) by swabbing method. Then, $6 \mathrm{~mm}$ diameter sterile paper discs soaked with $10 \mu \mathrm{L}$ of EOs were deposited on each agar medium plate. A disc soaked with $10 \mu \mathrm{L}$ of Diméthylsulfoxyde (DMSO) (Sigma-Aldrich, Buchs, Switzerland) was used as a negative control, while Imipenem $(10 \mu \mathrm{g}$, Oxoid, Basingstoke, UK) was used as a positive control for Pseudomonas aeruginosa and Gentamicin $(10 \mu \mathrm{g}$, Oxoid, Basingstoke, UK) for the other bacteria. Afterward, the plates were left for 30 minutes at room temperature to allow the diffusion of EOs and they were incubated at $37^{\circ} \mathrm{C}$ for 24 hours. After incubation, the inhibitory diameters of bacterial proliferation were measured included discs, and each test was done in triplicates.

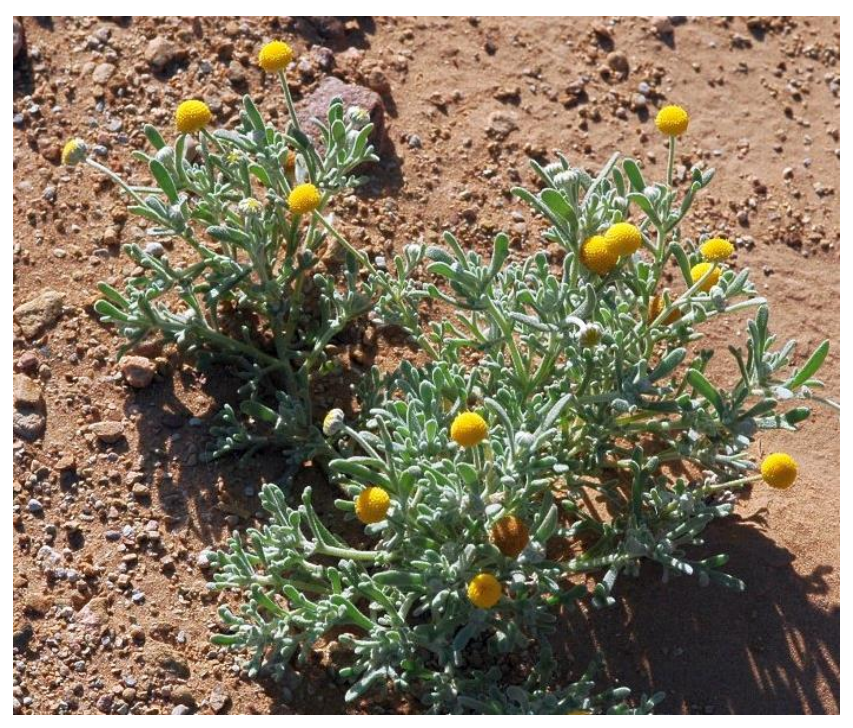

Figure 1. Brocchia cinerea 


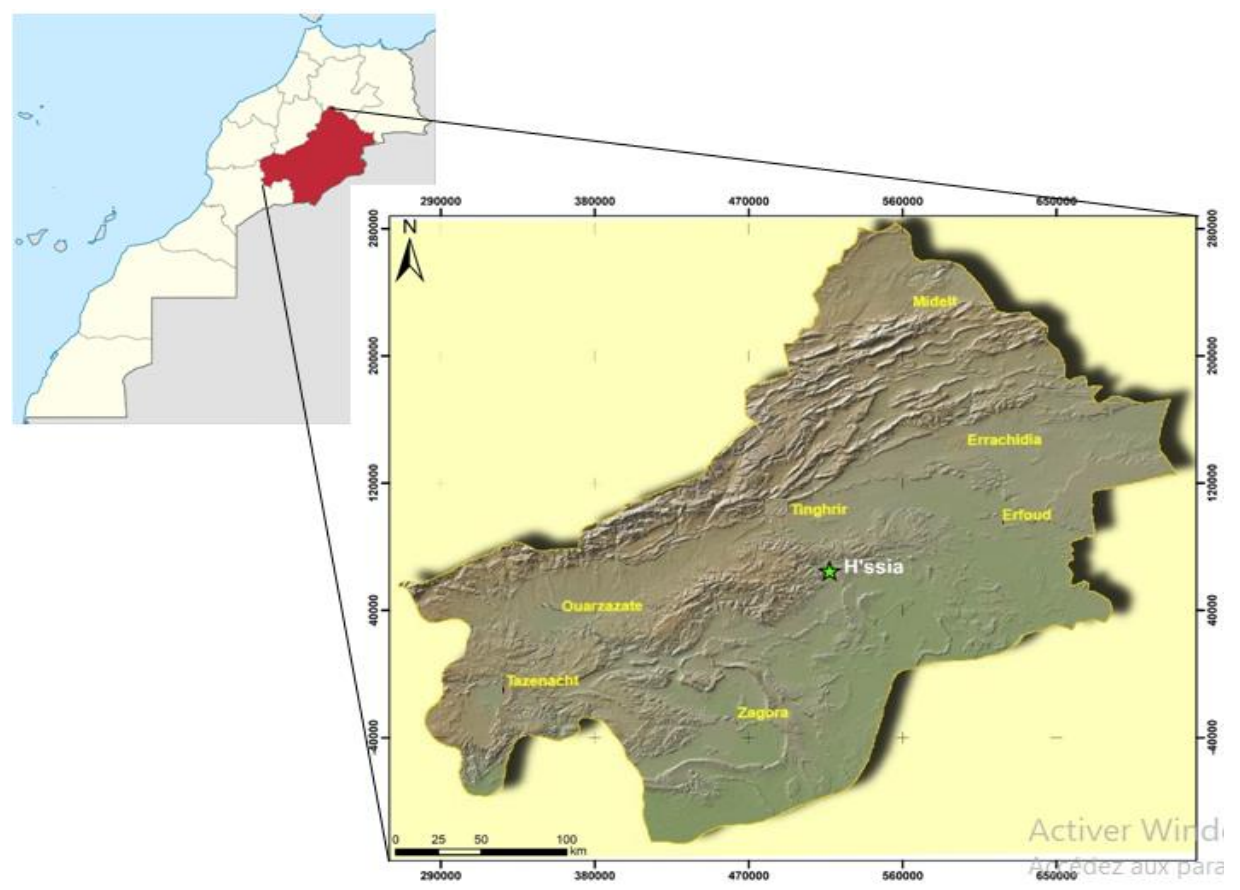

Figure 2. The geographical location of the area of study in H'ssia, Alnif city, Southeast of Morocco

\section{Microdilution method}

The determination of Minimal Inhibitory Concentration (MIC) was performed on 96 wells microplates as described previously by Chebaibi et al. (2016). Briefly, decreasing concentrations of EOs were prepared in DMSO, then $20 \mu \mathrm{L}$ of bacterial suspensions (0.5 Mac Farland) and $160 \mu \mathrm{L}$ of Mueller Hinton Broth (Biokar, Beauvais, France) were added to each well. One well without bacterial suspension was used as negative control and one well without EOs was used as a positive control. The microplates were incubated at $37^{\circ} \mathrm{C}$ for 24 hours. After the incubation, the MIC was evaluated by the addition of $40 \mu \mathrm{L}$ 2,3,5diphenyltetrazolium chloride [TTC] $(0.2 \mathrm{mg} / \mathrm{mL})$, which reveals the bacterial growth by the appearance of a reddish color. However, the Minimal Bactericidal Concentration (MBC) was evaluated by seeding $5 \mu \mathrm{L}$ of the wells which do not show any bacterial growth on Mueller Hinton agar (Biokar, Beauvais, France). Then, the plates were incubated at $37{ }^{\circ} \mathrm{C}$ for 24 hours.

MIC was determined as the lowest concentration of EOs that does not show bacterial growth. However, MBC corresponds to the lowest concentrations of EOs of which none of the bacteria colony was observed on Mueller Hinton agar. Moreover, the EOs can be classified with a bactericidal effect, if the ratio $\mathrm{MBC} / \mathrm{MIC}$ was inferior or equal to 4 and with a bacteriostatic effect if the ratio MBC/MIC was superior to 4 (Ed-Dra et al. 2018).

\section{Antioxidant activity}

The in vitro antioxidant activity of the extracted EOs was assessed by two different methods, Ferric Reduction Antioxidant Power «FRAP» method and DPPH free radical scavenging assay.

\section{Ferric Reducing Antioxidant Power (FRAP) method}

Ferric reducing $\left(\mathrm{Fe}^{3+}\right)$ capability of the studied EOs is determined according to the method described previously (Dorman et al. 2003), based on the reduction of $\mathrm{Fe}^{3+}$ present in $\mathrm{K}_{3} \mathrm{Fe}(\mathrm{CN})_{6}$ to $\mathrm{Fe}^{2+}$. Briefly, $1 \mathrm{~mL}$ of the ethanolic solution of different concentrations of EOs (from $0.15 \mathrm{mg} / \mathrm{mL}$ to $2.5 \mathrm{mg} / \mathrm{mL}$ ) was mixed with $2.5 \mathrm{~mL}$ of 0.2 $\mathrm{M}$ phosphate buffer solution $(\mathrm{pH}=6.6)$ and $2.5 \mathrm{~mL}$ of $1 \%$ potassium ferricyanide solution $\mathrm{K}_{3} \mathrm{Fe}(\mathrm{CN})_{6}$. The mixture was incubated at a temperature of $50^{\circ} \mathrm{C}$ in a water bath for 30 minutes and then cooled at room temperature. A volume of $2.5 \mathrm{~mL}$ of $10 \%$ trichloroacetic acid was added to stop the reaction. Afterward, the mixtures were centrifuged at 3000 rpm for 10 minutes. An aliquot of $2.5 \mathrm{~mL}$ of supernatant was mixed with $2.5 \mathrm{~mL}$ of distilled water and $0.5 \mathrm{~mL}$ of $0.1 \%$ aqueous solution of ferric chloride $\left(\mathrm{FeCl}_{3}\right)$. The absorbance was measured by spectrophotometer at $700 \mathrm{~nm}$ and ascorbic acid was used as a positive control.

\section{DPPH free radical scavenging activity}

DPPH scavenging activity of the tested EOs was conducted according to the protocol described previously with few modifications (Kazemi 2015). A series of EOs concentrations, ranging between $2.5 \mathrm{mg} / \mathrm{mL}$ and 0.045 $\mathrm{mg} / \mathrm{mL}$ was prepared in ethanol. Then, $2 \mathrm{~mL}$ of each concentration was mixed with $1 \mathrm{~mL}$ of ethanolic solution of DPPH (0.08 g/L). After homogenization, the mixture was incubated for 30 minutes at room temperature and in dark conditions. The absorbance was measured at $517 \mathrm{~nm}$ and the percentage of free radical scavenging activity (I\%) was calculated as follow (Sharififar et al. 2007): 
$\mathbf{I} \%=\frac{\left(\mathbf{A}_{\text {control }}-\mathbf{A}_{\text {sample }}\right)}{\mathbf{A}_{\text {blanc }}} \times 100$

Where:

A control: absorbance of the control (DPPH and ethanol)

A sample: sample absorbance with the DPPH solution

The concentration of EOs able to reduce $50 \%$ of DPPH $\left(\mathrm{IC}_{50}\right)$ was determined graphically by the linear regression of the plotted curve (Elsharkawy et al. 2018). Ascorbic acid was used as a positive control of this study.

\section{RESULTS AND DISCUSSIONS}

\section{The yield of essential oils extraction}

The yields of EOs extraction of fresh and dry aerial parts of $B$. cinerea were $0.31 \pm 0.091 \%$ and $0.55 \pm 0.14 \%$, respectively. The results showed that the drying operations of the plant had a significant effect on the yield of EOs. These results were in agreement with previous worldwide studies performed on the EOs of Lavandula angustifolia and Mentha pulegium (Ahmed et al. 2018; Mirjalili et al. 2019). Indeed, the yield of EOs depends on the physiological activities (enzymatic reactions) of plants. Therefore, the biosynthesis of EOs continues and accelerates after harvesting of the plant to respond to water stress, which explains the increase of EOs producing in the dry plants compared to the fresh plants.

On the other hand, other studies performed on dry aerial par of B. cinerea harvested from Zagora and Smara regions (Southern of Morocco) showed an extraction yield of $0.87 \%$ and 0.64, respectively (Ekhlil et al. 2016; El Bouzidi et al. 2011). This difference might be due to several factors, such as the degree of plant maturity, climate, soil composition, harvesting time, extraction method, and the geographical position of plant species (Elsharkawy et al. 2018; Ramos et al. 2012; 2020).

\section{Chemical composition of EOs of $B$. cinerea}

The results of GC-MS analysis of $B$. cinerea EOs were presented in Table 1, and the chemical structures of the major components were presented in Figure 3.

Thirty-eight components were identified in both EOs of fresh and dry aerial parts, representing respectively $99.02 \%$ and $98.52 \%$ of the total composition. The EO of the fresh aerial parts was dominated by thujone $(26.05 \%)$, cischrysanthenyl formate (15.64\%), 2-bornanone (15.40\%), santolina triene $(10.68 \%), 1,8$-cineol $(8.48 \%), p$-mentha1(7),8(10)-dien-9-ol (4.11\%), $\alpha$-phellandrene $(3.79 \%)$, camphene $(2.50 \%)$ and $\alpha$-pinene $(1.47 \%)$, representing $88.12 \%$ of the total composition. Whereas, the major components of dry aerial part EO were thujone $(22.37 \%)$, santolina triene $(16.45 \%)$, 1,8-cineol $(12.19 \%)$, cischrysanthenyl formate (12.03\%), 2-bornanone (11.56\%), $\alpha$ phellandrene $\quad(5.02 \%), \quad p$-mentha-1(7),8(10)-dien-9-ol (3.47\%), camphene $(2.42 \%)$ and $\alpha$-pinene $(1.89 \%)$ representing $83.93 \%$ of the total composition. The components identified in fresh aerial plants were represented by oxygenated monoterpenes $(59.78 \%)$, monoterpenes hydrocarbons (20.72\%), oxygenated sesquiterpenes $(0.59 \%)$, and oxygenated diterpenes $(0.17 \%)$. Whereas, the components identified in the dry aerial plant were represented by oxygenated monoterpenes (56.67\%), monoterpenes hydrocarbons (12.08\%), and oxygenated sesquiterpenes $(0.29 \%)$.

These results are similar to those reported by Ghouti and his group, which showed the dominance of $\alpha$-thujone $(32.35 \%)$ in Cotula cinerea (Ghouti et al. 2018a). Whereas, they are different from those reported by Djellouli and his group when studied the chemical composition of EO of dry aerial parts of $B$. cinerea collected in the mountains and the desert of Lahmar city in Southwest of Algeria (Djellouli et al. 2015). They identified 33 components with a dominance of (E)-citral (24.01\%), cis-limonene epoxide (18.26\%), thymol methyl ether $(15.04 \%)$, carvacrol $(15.03 \%)$, transcarveol $(13.79 \%)$, carvone $(3.06 \%)$ and trans-piperitol $(2.54 \%)$. Moreover, the main components detected belong to oxygenated monoterpenes $(95.40 \%)$, followed by monoterpene hydrocarbons $(2.17 \%)$, oxygenated sesquiterpenes $(0.68 \%)$, and hydrocarbon sesquiterpenes $(0.41 \%)$ (Djellouli et al. 2015). On the other hand, Ekhlil and his colleagues studied the chemical composition of EO of aerial part of $B$. cinerea harvested in the South of Morocco (Wadi Sagia Al Hamra, Smara) and identified 27 components with the dominance of iso-3-thujanol (47.38\%), santolinatriene $(11.67 \%)$ and camphor $(10.95 \%)$ (Ekhlil et al. 2016).

A study performed by Larbi and his group showed the presence of 40 components, representing $88 \%$ of the total EO, with the dominance of Trans-thujone (51.86\%), santalina triéne $(10.6 \%), \alpha$-pinene $(2.02 \%)$, sabinene (6.17\%), 1,8-cineole $(5.34 \%), \delta$-terpinene $(1.57 \%)$ and camphor $(2.63 \%)$ (Larbi et al. 2018). While santolina triene $(18.58 \%)$, thujone $(21.73 \%), 3$-carene $(30.99 \%)$, and camphor $(6.21 \%)$ were reported as the major components in a study performed by Atef and his group (Atef et al. 2015).

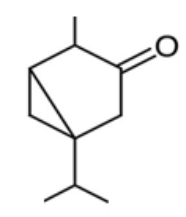

Thujone

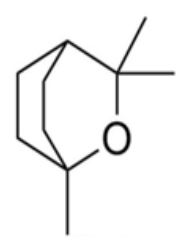

1.8-cineol

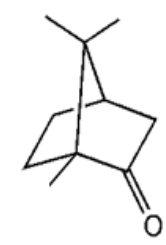

2-Bornanone

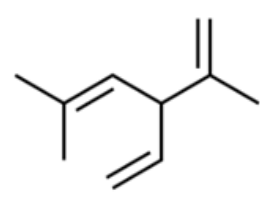

Santolina triene

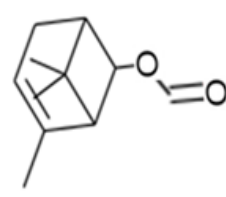

cis-Chrysanthenyl formate

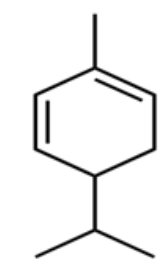

a-Phellandrene
Figure 3. The major components of Brocchia cinerea essential oils 
Table 1. Chemical composition of EOs extracted from fresh and dry aerial parts of Brocchia cinerea

\begin{tabular}{|c|c|c|c|c|}
\hline \multirow{2}{*}{ Components } & \multirow{2}{*}{$\begin{array}{c}\text { RT } \\
(\mathbf{m i n})\end{array}$} & \multirow{2}{*}{ Formula } & \multicolumn{2}{|c|}{ Relative abundance (\%) } \\
\hline & & & Fresh plant & Dry plant \\
\hline Santolina triene & 7.10 & $\mathrm{C}_{10} \mathrm{H}_{16}$ & 10.68 & 16.45 \\
\hline Bicyclo $[3,1,0]$ hex-2-ene,4-methylene-1-(1-methyle thyl)- & 7.68 & $\mathrm{C}_{10} \mathrm{H}_{16}$ & 0.62 & 0.84 \\
\hline$\alpha$-Pinene & 7.85 & $\mathrm{C}_{10} \mathrm{H}_{16}$ & 1.47 & 1.89 \\
\hline Benzene,(2-methylpropyl)- & 8.09 & $\mathrm{C}_{10} \mathrm{H}_{14}$ & 0.27 & 0.22 \\
\hline Camphene & 8.23 & $\mathrm{C}_{10} \mathrm{H}_{16}$ & 2.50 & 2.42 \\
\hline$\alpha$-Phellandrene & 9.12 & $\mathrm{C}_{10} \mathrm{H}_{16}$ & 3.79 & 5.02 \\
\hline$\alpha$-Myrcene & 9.90 & $\mathrm{C}_{10} \mathrm{H}_{16}$ & 0.25 & 0.30 \\
\hline 4-Terpinenyl acetate & 10.68 & $\mathrm{C}_{12} \mathrm{H}_{20} \mathrm{O}_{2}$ & 0.24 & 0.32 \\
\hline o-Cymene & 10.79 & $\mathrm{C}_{10} \mathrm{H}_{14}$ & 0.24 & 0.26 \\
\hline 2-Caren-4-ol & 10.89 & $\mathrm{C}_{10} \mathrm{H}_{16} \mathrm{O}$ & 0.33 & 0.23 \\
\hline 1,8-Cineol & 11.01 & $\mathrm{C}_{10} \mathrm{H}_{18} \mathrm{O}$ & 8.48 & 12.19 \\
\hline Limonene & 11.11 & $\mathrm{C}_{10} \mathrm{H}_{16}$ & 0.42 & 0.44 \\
\hline Ethanone, 1-(1,4-dimethyl-3-cyclohexen-1-yl)- & 11.62 & $\mathrm{C}_{10} \mathrm{H}_{16} \mathrm{O}$ & 0.20 & - \\
\hline Terpinene & 12.17 & $\mathrm{C}_{10} \mathrm{H}_{16}$ & 0.48 & 0.53 \\
\hline 5-Isopropyl-2-methylbicyclo [3.1.0] hexan-2-ol & 12.28 & $\mathrm{C}_{10} \mathrm{H}_{18} \mathrm{O}$ & - & 0.22 \\
\hline Butanoic acid, 3-hexenyl ester, (E)- & 12.45 & $\mathrm{C}_{10} \mathrm{H}_{18} \mathrm{O}_{2}$ & - & 0.13 \\
\hline 2-Carene & 13.21 & $\mathrm{C}_{10} \mathrm{H}_{16}$ & - & 0.16 \\
\hline Isopulegol & 13.37 & $\mathrm{C}_{10} \mathrm{H}_{18} \mathrm{O}$ & 0.34 & 0.49 \\
\hline Thujone & 13.87 & $\mathrm{C}_{10} \mathrm{H}_{16} \mathrm{O}$ & 26.05 & 22.37 \\
\hline 3-Heptadecen-5-yne, (Z)- & 14.03 & $\mathrm{C}_{10} \mathrm{H}_{14} \mathrm{O}$ & 1.35 & 1.81 \\
\hline trans-Verbenol & 14.26 & $\mathrm{C}_{10} \mathrm{H}_{16} \mathrm{O}$ & 0.27 & - \\
\hline 2-Bornanone & 14.52 & $\mathrm{C}_{10} \mathrm{H}_{16} \mathrm{O}$ & 15.40 & 11.56 \\
\hline trans-Chrysanthemal & 14.87 & $\mathrm{C}_{10} \mathrm{H}_{16} \mathrm{O}$ & 0.22 & 0.25 \\
\hline 1,5,7-Octatrien-3-ol, 3,7-dimethyl- & 15.16 & $\mathrm{C}_{10} \mathrm{H}_{16} \mathrm{O}$ & 0.38 & 0.21 \\
\hline Isoborneole & 15.59 & $\mathrm{C}_{10} \mathrm{H}_{18} \mathrm{O}$ & 0.13 & 0.24 \\
\hline p-Mentha-1(7),8(10)-dien-9-ol & 15.70 & $\mathrm{C}_{10} \mathrm{H}_{16} \mathrm{O}$ & 4.11 & 3.47 \\
\hline 4-Hexen-1-ol, 5-methyl-2-(1-methylethenyl)- & 15.90 & $\mathrm{C}_{10} \mathrm{H}_{18} \mathrm{O}$ & 0.20 & 0.24 \\
\hline Terpinen-4-ol & 16.07 & $\mathrm{C}_{10} \mathrm{H}_{18} \mathrm{O}$ & 1.44 & 1.44 \\
\hline$\alpha$-Terpineol & 16.50 & $\mathrm{C}_{10} \mathrm{H}_{18} \mathrm{O}$ & 0.88 & 0.98 \\
\hline $\mathrm{n}$-Valeric acid & 18.23 & $\mathrm{C}_{11} \mathrm{H}_{20} \mathrm{O}_{2}$ & 0.72 & 0.31 \\
\hline Myrtenyl acetate & 18.98 & $\mathrm{C}_{12} \mathrm{H}_{18} \mathrm{O}$ & 0.19 & 0.15 \\
\hline cis-Chrysanthenyl formate & 19.62 & $\mathrm{C}_{11} \mathrm{H}_{16} \mathrm{O}_{2}$ & 15.64 & 12.03 \\
\hline Bornyl acetate & 19.79 & $\mathrm{C}_{12} \mathrm{H}_{20} \mathrm{O}_{2}$ & 0.41 & 0.41 \\
\hline 2,6-Octadien-1-ol, 3,7-dimethyl-, acetate, (Z)- & 20.16 & $\mathrm{C}_{12} \mathrm{H}_{20} \mathrm{O}_{2}$ & 0.35 & 0.30 \\
\hline 2-Cyclopenten-1-one, 3-methyl-2-(2-pentenyl)-,(Z)- & 23.01 & $\mathrm{C}_{11} \mathrm{H}_{16} \mathrm{O}$ & 0.24 & 0.18 \\
\hline m-Camphorene & 38.78 & $\mathrm{C}_{20} \mathrm{H}_{32}$ & 0.17 & - \\
\hline Bergamotol, Z- $\alpha$-trans- & 40.00 & $\mathrm{C}_{15} \mathrm{H}_{24} \mathrm{O}$ & 0.40 & 0.29 \\
\hline Lanceol, cis & 40.17 & $\mathrm{C}_{15} \mathrm{H}_{24} \mathrm{O}$ & 0.19 & 0.17 \\
\hline Total identified (\%) & & & 99.02 & 98.52 \\
\hline \multicolumn{5}{|l|}{ Grouped compounds } \\
\hline Monoterpene hydrocarbons & & & 20.72 & 12.08 \\
\hline Oxygenated monoterpenes & & & 59.78 & 56.67 \\
\hline Oxygenated sesquiterpenes & & & 0.59 & 0.29 \\
\hline Oxygenated diterpenes & & & 0.17 & - \\
\hline Others & & & 17.79 & 15.36 \\
\hline
\end{tabular}

During drying process, three new components were produced (5-Isopropyl-2 methylbicyclo [3,1,0] hexan-2-ol, Butanoic acid, and 2-carene) and three components were disappeared (Ethanone; trans-verbenol and $\mathrm{m}$ camphorene). These results were supported by a study performed by Ahmed and his group, which showed that dry processing methods had a significant effect on the chemical composition of EOs (Ahmed et al. 2018).

It is noted that the difference observed between the chemical composition of $B$. cinerea EOs could be explained by the specific climate of arid and Saharan regions, geographical factors such as altitude and soil composition, harvesting and drying conditions, storage period, temperature, and extraction methods (Ben Haj Yahia et al. 2019; Elsharkawy et al. 2018; Pirbalouti et al. 2013; Ramos et al. 2020; Zarai et al. 2012).

\section{Antibacterial activity}

The antibacterial activity performed by the disc diffusion method showed that the EOs of fresh and dry aerial part of $B$. cinerea had a variable inhibitory activity against the tested bacteria (Figure 4). 


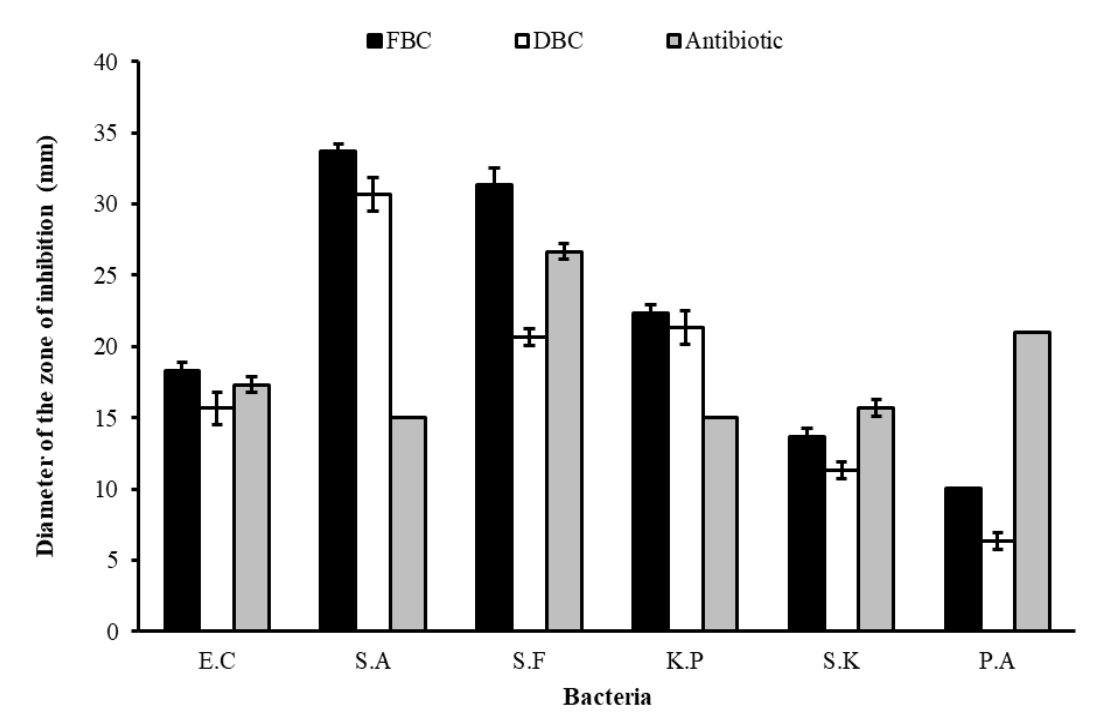

Figure 4. Antibacterial activity of EOs of fresh (FBC) and dry (DBC) aerial parts of Brocchia cinerea. E.C: Escherichia coli, S.A: Staphylococcus aureus, S.F: Streptococcus faecalis, K.P: Klebsiella pneumoniae, S.K: Salmonella Kentucky, P.A: Pseudomonas aeruginosa.

Table 2. MCI and MBC of EOs from fresh (FBC) and dry (DBC) aerial parts of Brocchia cinerea

\begin{tabular}{lcccc}
\hline & \multicolumn{2}{c}{ FBC } & \multicolumn{2}{c}{ DBC } \\
\cline { 2 - 5 } & $\begin{array}{c}\text { MIC } \\
(\mathbf{m g} / \mathbf{m L})\end{array}$ & $\begin{array}{c}\mathbf{M B C} \\
(\mathbf{m g} / \mathbf{m L})\end{array}$ & $\begin{array}{c}\text { MIC } \\
(\mathbf{m g} / \mathbf{m L})\end{array}$ & $\begin{array}{c}\mathbf{M B C} \\
(\mathbf{m g} / \mathbf{m L})\end{array}$ \\
\hline S.A & 0.39 & 0.39 & 0.39 & 0.39 \\
S.F & 1.56 & 1.56 & 1.56 & 1.56 \\
K.P & 3.12 & 3.12 & 1.56 & 3.12 \\
E.C & 6.25 & 6.25 & 3.12 & 3.12 \\
S.K & 12.5 & 12.5 & 12.5 & 12.5 \\
P.A & $*$ & $*$ & $*$ & $*$ \\
\hline
\end{tabular}

*No effect, E.C: Escherichia coli, S.A: Staphylococcus aureus, S.F: Streptococcus faecalis, K.P: Klebsiella pneumoniae, S.K: Salmonella Kentucky, P.A: Pseudomonas aeruginosa

The EO extracted from the fresh aerial part presents a high inhibitory activity against $S$. aureus, $S$. faecalis, $K$. pneumoniae, E. coli, and $S$. Kentucky, compared to the EO extracted from the dry aerial part. However, the tested EOs present a weak activity against $P$. aeruginosa. The results of this study showed that the MIC and MBC vary between 0.39 and $12.50 \mathrm{mg} / \mathrm{mL}$ (Table 2), except for P. aeruginosa, which was resistant to the high used concentrations. Moreover, the ratio $\mathrm{MBC} / \mathrm{MIC}$ is equal to 1 , which explains that these EOs present a bactericidal effect (EdDra et al. 2018). These results confirm previous studies, which reported that $B$. cinerea $\mathrm{EO}$ had a great to moderate antibacterial activity (Figueiredo et al. 2008; Atef et al. 2015; Ekhlil et al. 2016).

The difference in the effect of EOs on bacteria can be explained by its chemical composition, functional groups of its majority components, chemical structures of components, and their proportions ( Kalemba and Kunicka 2003; Soković et al. 2010; Ed-Dra et al. 2020). However, the synergistic effect between the majority and minority components of EOs is also significant in the determination of the antibacterial activity (Ed-Dra et al. 2020; Ramos et al. 2012; Sonboli et al. 2006).

In the present research, the inhibition of bacteria may be explained by the richness of these EOs in thujone, santalina triene, 2-bornanone and 1,8-cineol, as well as the interaction between different components. However, several studies were showed the greater activity of 1,8cineole and terpinen-4-ol against multidrug resistance bacteria (Kalemba and Kunicka 2003; Mulyaningsih et al. 2010).

The antibacterial properties of these EOs were suspected to be associated with their high contents of oxygenated monoterpene $(59.78 \%$ in fresh plant and 56.67 $\%$ in the dry plant), which make them more active against Gram-positive than Gram-negative bacteria. This result is in agreement with many studies performed on other plant species like Eucalyptus cinerea, Eucalyptus globulus, Rosmarinus officinalis, Salvia officinalis, Citrus limon (Elaissi et al. 2011; Radulović et al. 2017; Ed-Dra et al. 2020). Furthermore, the percentage of the acetone was $41.65 \%$ in fresh plant and $33.93 \%$ in the dry plant, including the presence of thujone and 2-bornanone, which are described as being very active against microorganisms (Radulović et al. 2017; Castner and Henry 2018; Sasikala et al. 2019). However, the alcoholic components present in the EOs possess a significant bactericidal activity (Ed-Dra et al. 2020), in which the percentage of alcohols in the EOs extracted from the fresh and dry aerial part of $B$. cinerea were $8.08 \%$ and $7.52 \%$ respectively. Whereas, hydrocarbon derivatives possess lower antimicrobial properties their lower water solubility limits their diffusion through the medium. Therefore, hydrocarbons tend to be relatively inactive regardless of their structural type, and this inactivity is closely related to their limited hydrogen bound capacity and water solubility (Soković et al. 2010). 
Nevertheless, the results of this study showed that Gram-positive bacteria like $S$. aureus and S. faecalis are more sensitive to EOs than Gram-negative bacteria. These results are in agreement with the findings of Cantore et al. (2004), who reported that Gram-positive bacteria are more sensitive to EOs than Gram-negative bacteria. This sensitivity is related to the structure of the cell wall (Kalemba and Kunicka 2003). Indeed, the cell wall of Gram-positive bacteria is organized in such a way that it offers less protection against foreign substances (HarkatMadouri et al. 2015). However, the resistance of $P$. aeruginosa to EOs can be explained by a masking effect of the inhibitory substances contained in these EOs in addition to the variability response of the bacteria to the EOs (Marotta et al. 2016). This ascertainment was confirmed by the results obtained by Atef and his group, which showed that $P$. aeruginosa presents a strong resistance even at high concentrations of the EO of $B$. cinerea (Atef et al. 2015). Generally, the resistance of Gram-negative bacteria for example $P$. aeruginosa has been attributed to the presence of a hydrophilic outer membrane containing a hydrophilic polysaccharide chain, which acts as a barrier hydrophobic against EOs (Kalemba and Kunicka 2003; Mulyaningsih et al. 2010).

\section{Antioxidant activity}

The determination of antioxidant power of EOs of fresh and dry aerial parts of $B$. cinerea was carried out by FRAP and DPPH assays. The EOs of fresh and dry aerial parts of $B$. cinerea had a similar capacity to reduce iron with an optical density of 0.652 and 0.622 , respectively (Figure 5).

These EOs had a moderate reducing power compared to ascorbic acid. At a concentration of $0.375 \mathrm{mg} / \mathrm{mL}$, the absorbance of EOs becomes almost constant, in which the OD does not exceed 0.7 at a maximum concentration of 3 $\mathrm{mg} / \mathrm{mL}$, whereas the OD of ascorbic acid achieved 1.519 at the same concentration.

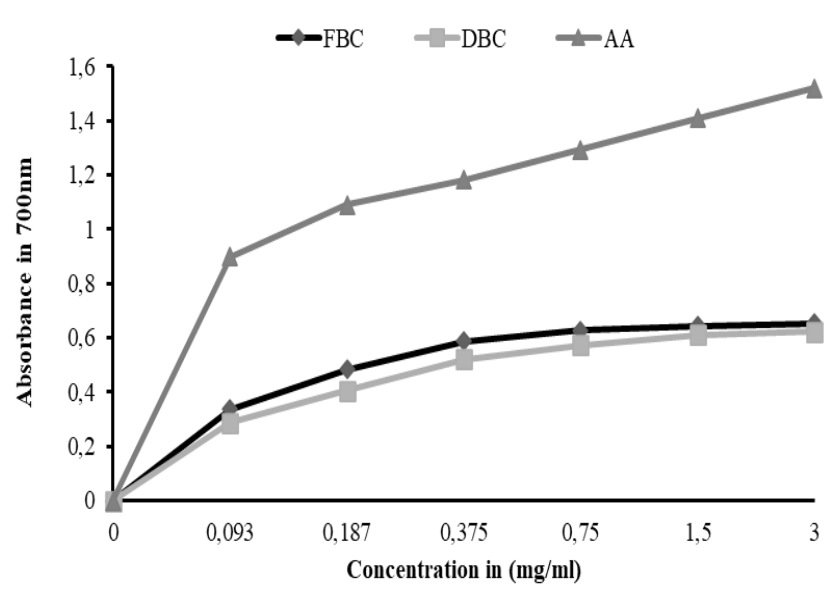

Figure 5. Antioxidant activity of Brocchia cinerea EOs by FRAP method. FBC: Fresh B. cinerea, DBC: Dry B. cinerea, AA: Ascorbic acid
It seems that the inhibition percentage of the free radical increases with the increase of the concentration either for ascorbic acid and EOs. The inhibition percentage of free radical for the two EOs was less than the ascorbic acid, in all the tested concentrations. For a maximal concentration of $5 \mathrm{mg} / \mathrm{mL}$, the inhibition percentages of the EOs extracted from the fresh aerial parts and that extracted from the dry aerial parts were $59.12 \pm 2.41 \%$ and $57.04 \pm 1.26 \%$, respectively. However, the inhibition percentage of ascorbic acid was $94.08 \pm 0.93 \%$.

For comparative purposes, another parameter $\mathrm{IC}_{50}$ was evaluated which expresses the number of antioxidants required to reduce the free radical concentration by $50 \%$ (a lower value of $\mathrm{IC}_{50}$ means a high antioxidant activity) (Larbi et al. 2018). The $\mathrm{IC}_{50}$ values were graphically determined by linear regression (Figure 6).

The results showed that ascorbic acid has an $\mathrm{IC}_{50}$ of $0.234 \mathrm{mg} / \mathrm{mL}$, which is lower than those recorded by the EOs of fresh and dry aerial parts of $B$. cinerea (3.781 $\mathrm{mg} / \mathrm{mL}$ and $4.122 \mathrm{mg} / \mathrm{mL}$ respectively) (Figure 7).

EOs were quite complex mixtures, and this complexity makes it difficult to explain their activity patterns. The antioxidant activity of certain phenolic compounds and other pure substances was previously demonstrated, while the antioxidant power of EOs refers often to such concepts as synergism, antagonism, and additively (Harkat-Madouri et al. 2015; Sasikala et al. 2019). Generally, the antioxidant activity of EOs depends on the content of phenolic compounds and the reaction activity of the phenol towards the chain-carrying peroxyl radicals and the stability of the phenoxyl radical formed in the reaction (Harkat-Madouri et al. 2015). As shown in the two different assays, the $B$. cinerea EOs exhibited a moderate activity, attributed to the present higher amount of oxygenated monoterpenes, which promotes its property of being a radical scavenging agent. On the other hand, sesquiterpene hydrocarbons and their oxygenated derivatives had very low antioxidant activity (Ruberto and Baratta 2000).

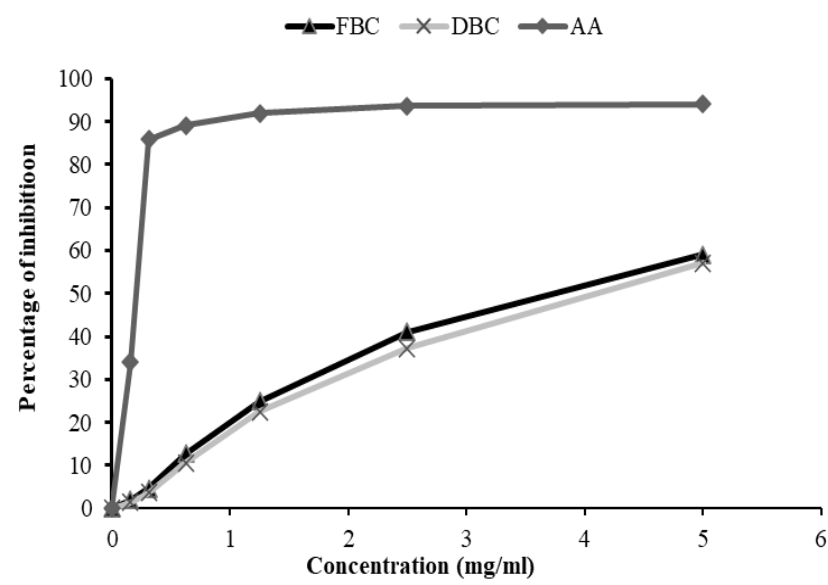

Figure 6. Antioxidant activity of Brocchia cinerea EOs measured by DPPH method. FBC: Fresh B. cinerea, DBC: Dry B. cinerea, AA: Ascorbic acid 


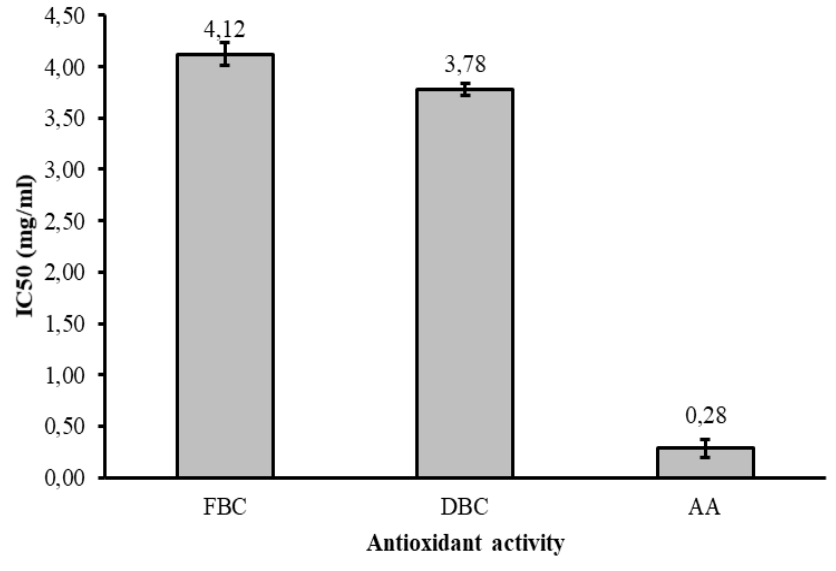

Figure 7. $\mathrm{IC}_{50}$ of fresh (FBC), dry (DBC) aerial parts of Brocchia cinerea and Ascorbic acid (AA)

The antioxidant activity observed in this study can be explained to the components: thujone, 1,8-cineol, and santolina triene, which are present with high percentages. Terpenes such as pinene, limonene, myrcene, sabinene, and terpinolene are known to have good antioxidant properties, even if the low percentage observed of these compounds in our EOs may be responsible for this antioxidant power observed (Martins et al. 2014). However, several factors can influence the chemical composition of the EO and also its antioxidant activity, for example, during the extraction by hydrodistillation, degradation of the bioactive compounds can be achieved. Indeed, the hydrodistillation can lead to the thermal degradation, hydrolysis, and solubilization of the bioactive compounds in water, thus changing their antioxidant capacity. Furthermore, the water used in hydrodistillation makes several antioxidants unstable or degrades them by enzymatic action in the wet plant material (Harkat-Madouri et al. 2015).

In conclusion, the current work focused on the study of the $B$. cinerea species which belongs to the family Asteraceae, this plant is considered one of the most important categories in the flora of Southeast Morocco as well as Algeria, and it is mostly used by traditional therapists. In the present study, EOs showed potency antibacterial properties against Gram-positive and Gramnegative bacteria which may be directly associated with their major components such as oxygenated monoterpenes (thujone, 1,8-cineol, 2-bornanone) which can act as antibacterial agents or to the presence of synergic effect between the major and minor components of EOs. Therefore, $B$. cinerea can be used as an inexpensive source of natural antibacterial substance to treat pathogenic bacteria and to extend the shelf life of food products. Moreover, this study can provide a basis for the development of a new generation of natural antibacterial agents that could be used against rebellious infections. Furthermore, the antioxidant activity has been proved that these EOs showed a moderate activity to reduce ferrous iron to ferric iron and to trap the free radicals from DPPH compared to ascorbic acid. This plant may be used as a potential source of natural substances that could be used in some medical, pharmaceutical, and agri-food sectors as alternatives of chemical compounds to inhibit the growth of pathogenic bacteria and to extend the shelf life of food products.

\section{ACKNOWLEDGEMENTS}

The authors gratefully acknowledge Prof. Mohamed Ibn Tattou and Hamid Khammar, Scientific Institute, Rabat, of Morocco for the identification of the plant.

\section{REFERENCES}

Adekenov SM. 1995. Sesquiterpene lactones from plants of the family Asteraceae in the Kazakhstan flora and their biological activity. Chem Nat Compd 31: 21-25. DOI: 10.1007/BF01167564.

Ahmed A, Ayoub K, Chaima AJ, Hanaa L, Abdelaziz C. 2018. Effect of drying methods on yield, chemical composition and bioactivities of essential oil obtained from Moroccan Mentha pulegium L. Biocatal Agric Biotechnol 16: 638-643. DOI: 10.1016/j.bcab.2018.10.016.

Atef C, Boualem M, Cherif MM, Youcef H, Azzedine C. 2015. Chemical composition and antimicrobial activity of essential oils in Xerophytic plant Cotula cinerea Del (Asteraceae) during two stages of development: Flowering and fruiting. J Appl Pharm Sci 5: 29-34. DOI: DOI: $10.7324 / J A P S .2015 .50306$.

Barkaoui M, Katiri A, Boubaker H, Msanda F. 2017. Ethnobotanical survey of medicinal plants used in the traditional treatment of diabetes in Chtouka Ait Baha and Tiznit (Western Anti-Atlas), Morocco. J Ethnopharmacol 198: 338-350. DOI: 10.1016/j.jep.2017.01.023.

Ben Haj Yahia I, Jaouadi R, Trimech R, Boussaid M, Zaouali Y. 2019. Variation of chemical composition and antioxidant activity of essential oils of Mentha $x$ rotundifolia (L.) Huds. (Lamiaceae) collected from different bioclimatic areas of Tunisia. Biochem Syst Ecol 84: 8-16. DOI: 10.1016/j.bse.2019.03.001.

Castner E, Henry GE. 2018. Synthesis of thujol esters as potential antibacterial agents. American Chemical Society 255th National Conference, CHED-1490, March 2018.

Chebaibi A, Marouf Z, Rhazi-Filali F, Fahim M, Ed-Dra A. 2016. Evaluation of antimicrobial activity of essential oils from seven Moroccan medicinal plants. Phytotherapie 14: 355-362.

Cantore LP, Iacobellis NS, De Marco A, Capasso F, Senatore F. 2004. Antibacterial activity of Coriandrum sativum L. and Foeniculum vulgare Miller var. vulgare (Miller) essential oils. J Agric Food Chem 52: 7862-7866. DOI: 10.1021/jf0493122.

Djellouli M, Benmehdi H, Mammeri S, Moussaoui A, Ziane L, Hamidi N. 2015. Chemical constituents in the essential oil of the endemic plant Cotula cinerea (Del.) from the southwest of Algeria. Asian Pac J Trop Biomed 5: 870-873. DOI: 10.1016/j.apjtb.2015.06.007.

Dorman HJD, Peltoketo A, Hiltunen R, Tikkanen MJ. 2003. Characterisation of the antioxidant properties of de-odourised aqueous extracts from selected Lamiaceae herbs. Food Chem 83: 255 262. DOI: 10.1016/S0308-8146(03)00088-8.

Ed-Dra A, Filai FR, Bou-Idra M, Zekkori B, Bouymajane A, Moukrad N, Benhallam F, Bentayeb A. 2018. Application of Mentha suaveolens essential oil as an antimicrobial agent in fresh turkey sausages. J Appl Biol Biotechnol 6: 7-12. DOI: DOI: 10.7324/JABB.2018.60102.

Ed-Dra A, Filali FR, Lo Presti V, Zekkori B, Nalbone L, Bouymajane A, Trabelsi N, Lamberta F, Bentayeb A, Giuffrida A, Giarratana F. 2020. Chemical composition, antioxidant capacity and antibacterial action of five Moroccan essential oils against Listeria monocytogenes and different serotypes of Salmonella enterica. Microb Pathog 149: 104510. DOI: 10.1016/j.micpath.2020.104510.

Ekhlil B, Mohamed G, Satrani B, Alaoui MB, Rachid R, Abdellah F, Amusant N, Chaouch A. 2016. Chemical quality, antibacterial and antifungal activities of Cotula cinerea essential oil from South Morocco. Environ Sci An Indian J 12: 209-216.

El-Hilaly J, Hmammouchi M, Lyoussi B. 2003. Ethnobotanical studies and economic evaluation of medicinal plants in Taounate province 
(Northern Morocco). J Ethnopharmacol 86: 149-158. DOI: 10.1016/S0378-8741(03)00012-6.

El Bouzidi L, Abbad A, Fattarsi K, Hassani L, Leach D, Markouk M, Legendre L, Bekkouche K. 2011. Chemical composition and anticandidal properties of the essential oil isolated from aerial parts of Cotula cinerea: A rare and threatened medicinal plant in Morocco. Nat Prod Commun 6: 1491-1494. DOI: $10.1177 / 1934578 X 1100601021$.

Elaissi A, Salah KH, Mabrouk S, Larbi KM, Chemli R, Harzallah-Skhiri F. 2011. Antibacterial activity and chemical composition of 20 Eucalyptus species' essential oils. Food Chem 129: 1427-1434. DOI: 10.1016/j.foodchem.2011.05.100.

Elsharkawy ER, Ed-Dra A, Alghanem S, Abdallah EM. 2018. Comparative studies of chemical compostion, antimicrobial and antioxidant activity of essential oil of some species from genus Artemisia. J Nat Remedies 18: 10-20. DOI: DOI $10.18311 / \mathrm{jnr} / 2018 / 20052$.

Figueiredo AC, Barroso JG, Pedro LG, Scheffer JJC. 2008. Factors affecting secondary metabolite production in plants: Volatile components and essential oils. Flavour Fragr J 23: 213-226. DOI: $10.1002 / \mathrm{ffj} .1875$

Ghouti D, Lazouni HA, Moussaoui A, Chabane Sari D. 2018a. Chemical profile, in vitro antibacterial and antioxidant activities of Juniperus phoenicea L. and Cotula cinerea (Del.) essential oils from Southwestern Algeria. Phytothérapie 16: S74-S83. DOI: 10.3166/phyto-2018-0061.

Ghouti D, Rached W, Abdallah M, Pires T, Calhelha RC, Alves MJ, Abderrahmane LH, Barros L, Ferreira ICFR. 2018b. Phenolic profile, and in vitro bioactive potential of Saharan Juniperus phoenicea $\mathrm{L}$. and Cotula cinerea (Del) growing in Algeria. Food Funct 9: 46644672. DOI: $10.1039 / \mathrm{C} 8 \mathrm{FO} 01392 \mathrm{~F}$

Guaouguaou F, Ahl Bebaha MA, Yadlapalli S, Taghzouti K, Es-Safi NE. 2019. Structural characterization of bioactive compounds in Cotula cinerea extracts by ultra-high-performance liquid chromatography with photodiode array and high-resolution time-of-flight mass spectrometry detectors (UHPLC-PDA-ESI-ToF/HRMS). Rapid Commun Mass Spectrom 34 (8): e8695. DOI: 10.1002/rcm.8695.

Harkat-Madouri L, Asma B, Madani K, Bey-Ould Si Said Z, Rigou P, Grenier D, Allalou H, Remini H, Adjaoud A, Boulekbache-Makhlouf L. 2015. Chemical composition, antibacterial and antioxidant activities of essential oil of Eucalyptus globulus from Algeria. Ind Crops Prod 78: 148-153. DOI: 10.1016/j.indcrop.2015.10.015.

Jamila F, Mostafa E. 2014. Ethnobotanical survey of medicinal plants used by people in Oriental Morocco to manage various ailments. J Ethnopharmacol 154: 76-87. DOI: 10.1016/j.jep.2014.03.016.

Kalemba D, Kunicka A. 2003. Antibacterial and antifungal properties of essential oils. Curr Med Chem 10: 813-829. DOI: $10.2174 / 0929867033457719$.

Kazemi M. 2015. Chemical composition and antimicrobial, antioxidant activities and anti-inflammatory potential of Achillea millefolium $\mathrm{L}$., Anethum graveolens L., and Carum copticum L. essential oils. J Herb Med 5: 217-222. DOI: 10.1016/j.hermed.2015.09.001

Lakhdar M. 2018. Traditional uses, phytochemistry and biological activities of Cotula cinerea Del: A review. Trop J Pharm Res 17: 365373. DOI: 10.4314/tjpr.v17i2.24.

Larbi BAM, Naima B, Elsharkawy ER, Salah N. 2018. Phytochemical characterization, in-vitro cytotoxic and antibacterial activity of Cotula cinerea (Delile) Vis essential oil. J Nat Remedies 18. DOI: $10.18311 / \mathrm{jnr} / 2018 / 22380$.

Markouk M, Redwane A, Lazrek HB, Jana M, Benjama A. 1999. Antibacterial activity of Cotula cinerea extracts. Fitoterapia 70: 314316. DOI: 10.1016/S0367-326X(99)00042-8.

Markouk M, Bekkouche K, Larhsini M, Bousaid M, Lazrek HB, Jana M. 2000. Evaluation of some Maroccan medicinal plant extracts for larvicidal activity. J Ethnopharmacol 73: 293-297. DOI: 10.1016/S0378-8741(00)00257-9.

Marotta SM, Giarratana F, Parco M, Neri D, Ziino G, Giuffrida A, Panebianco A. 2016. Evaluation of the antibacterial activity of bergamot essential oils on different Listeria monocytogenes strains. Ital J Food Saf 5: 6176. DOI: 10.4081/ijfs.2016.6176.

Martins MDR, Arantes S, Candeias F, Tinoco MT, Cruz-Morais J. 2014. Antioxidant, antimicrobial and toxicological properties of Schinus molle L. essential oils. J Ethnopharmacol 151: 485-492. DOI: 10.1016/j.jep.2013.10.063.

Mirjalili MH, Salehi P, Vala MM, Ghorbanpour M. 2019. The effect of drying methods on yield and chemical constituents of the essential oil in Lavandula angustifolia Mill. (Lamiaceae). Plant Physiol. Reports 24: 96-103. DOI: $10.1007 / \mathrm{s} 40502-019-0438-4$.

Mrabti HN, Jaradat N, Kachmar MR, Ed-Dra A, Ouahbi A, Cherrah Y, El Abbes Faouzi M. 2019. Integrative herbal treatments of diabetes in Beni Mellal region of Morocco. J Integr Med 17 (2): 93-99. DOI: 10.1016/j.joim.2019.01.001

Mulyaningsih S, Sporer F, Zimmermann S, Reichling J, Wink M. 2010. Synergistic properties of the terpenoids aromadendrene and 1,8cineole from the essential oil of Eucalyptus globulus against antibiotic-susceptible and antibiotic-resistant pathogens. Phytomedicine 17: 1061-1066. DOI: 10.1016/j.phymed.2010.06.018.

Pirbalouti AG, Oraie M, Pouriamehr M, Babadi ES. 2013. Effects of drying methods on qualitative and quantitative of the essential oil of Bakhtiari savory (Satureja bachtiarica Bunge.). Ind Crops Prod 46: 324-327. DOI: 10.1016/j.indcrop.2013.02.014.

Radulović NS, Genčić MS, Stojanović NM, Randjelović PJ, StojanovićRadić ZZ, Stojiljković NI. 2017. Toxic essential oils. Part V: Behaviour modulating and toxic properties of thujones and thujonecontaining essential oils of Salvia officinalis L., Artemisia absinthium L., Thuja occidentalis L. and Tanacetum vulgare L. Food Chem Toxicol 105: 355-369. DOI: 10.1016/j.fct.2017.04.044

Ramos C, Teixeira B, Batista I, Matos O, Serrano C, Neng NR, Nogueira JMF, Nunes ML, Marques A. 2012. Antioxidant and antibacterial activity of essential oil and extracts of bay laurel Laurus nobilis Linnaeus (Lauraceae) from Portugal. Nat Prod Res 26: 518-529. DOI: 10.1080/14786419.2010.531478.

Ramos YJ, Machado D de B, Queiroz GA de, Guimarães EF, Defaveri ACAE, Moreira D de L. 2020. Chemical composition of the essential oils of circadian rhythm and of different vegetative parts from Piper mollicomum Kunth - A medicinal plant from Brazil. Biochem Syst Ecol 92: 104-116. DOI: 10.1016/j.bse.2020.104116.

Ruberto G, Baratta MT. 2000. Antioxidant activity of selected essential oil components in two lipid model systems. Food Chem 69: 167-174. DOI: $10.1016 / \mathrm{S} 0308-8146(99) 00247-2$.

Sasikala P, Ganesan S, Jayaseelan T, Azhagumadhavan S, Padma M, Senthilkumar S, Mani P. 2019. Phytochemicals and GC-MS analysis of bioactive compounds present in ethanolic leaves extract of Taraxacum officinale (L). J Drug Deliv Ther 9: 90-94. DOI: 10.22270/jddt.v9i1.2175.

Sharififar F, Moshafi MH, Mansouri SH, Khodashenas M, Khoshnoodi M. 2007. In vitro evaluation of antibacterial and antioxidant activities of the essential oil and methanol extract of endemic Zataria multiflora Boiss. Food Control 18: 800-805. DOI: 10.1016/j.foodcont.2006.04.002.

Silalahi M, Nisyawat. 2018. The ethnobotanical study of edible and medicinal plants in the home garden of Batak Karo sub-ethnic in North Sumatra, Indonesia. Biodiversitas 19: 229-238. DOI: 10.13057/biodiv/d190131.

Soković M, Glamočlija J, Marin PD, Brkić D, Van Griensven LJL. 2010. Antibacterial effects of the essential oils of commonly consumed medicinal herbs using an in vitro model. Molecules 15: 7532-7546. DOI: $10.3390 /$ molecules15117532.

Sonboli A, Babakhani B, Mehrabian AR. 2006. Antimicrobial activity of six constituents of essential oil from Salvia. Zeitschrift fur Naturforsch. - Sect. C J Biosci 61: 160-164.

Zarai Z, Chobba I Ben, Mansour R Ben, Békir A, Gharsallah N, Kadri A. 2012. Essential oil of the leaves of Ricinus communis L.: In vitro cytotoxicity and antimicrobial properties. Lipids Health Dis 11: 1-7. DOI: 10.1186/1476-511X-11-102. 